\title{
PENGARUH DISIPLIN KERJA TERHADAP PRODUKTIVITAS KERJA KARYAWAN BAGIAN PRODUKSI PADA PT. TIRTA MUMBUL JAYA ABADI TAHUN 2016
}

\author{
Putu Juni Wirawan ${ }^{1}$, Iyus Akhmad Haris ${ }^{2}$, Kadek Rai Suwena ${ }^{3}$ \\ Jurusan Pendidikan Ekonomi \\ Universitas Pendidikan Ganesha \\ Singaraja, Indonesia \\ e-mail: juniwirawan18@yahoo.com¹, iyus.haris@gmail.com², \\ kadek suwena@yahoo.co.id ${ }^{3}$
}

\begin{abstract}
Abstrak
Penelitian ini bertujuan untuk mengetahui disiplin kerja karyawan, produktivitas kerja karyawan, dan pengaruh disiplin kerja terhadap produktivitas kerja karyawan bagian produksi pada PT. Tirta Mumbul Jaya Abadi. Penelitian ini merupakan jenis penelitian kausal. Populasi dalam penelitian ini adalah karyawan bagian produksi pada PT. Tirta Mumbul Jaya Abadi yang berjumlah 42 orang. Data dikumpulkan dengan menggunakan kuesioner dan dianalisis menggunakan analisis deskriptif dan analisis regresi linear sederhana dengan bantuan program Statistical Package for Social Sciences (SPSS) for windows versi 16. Hasil penelitian menunjukkan bahwa disiplin kerja karyawan bagian produksi pada PT. Tirta Mumbul Jaya Abadi berada pada kategori sangat baik dengan skor sebesar 3.727, sedangkan produktivitas kerja karyawan bagian produksi pada PT. Tirta Mumbul Jaya Abadi berada pada kategori sangat tinggi dengan skor sebesar 2.368. Dari hasil analisis diketahui bahwa disiplin kerja berpengaruh signifikan terhadap produktivitas kerja ditunjukkan dari nilai $\mathrm{t}_{\text {hitung }}>$ $\mathrm{t}_{\text {tabel }}(4.756>2.021)$ atau $p$-value $<\alpha(0.000<0.05)$.
\end{abstract}

Kata kunci : disiplin kerja, produktivitas kerja.

\begin{abstract}
This study aims to determine employee work discipline, employee work productivity, and the influence of work discipline on work productivity of employees of production at PT. Tirta Mumbul Jaya Abadi. This study is a type of causal research. Population in this research is employees of production at PT. Tirta Mumbul Jaya Abadi which amounted to 42 people. The data were collected by using questionnaire and analyzed by using descriptive analysis and simple linear regression analysis with the help of Statistical Package for Social Sciences (SPSS) program for windows version 16. The results showed that the work discipline of production employee at PT. Tirta Mumbul Jaya Abadi is in very good category with score of 3,727 , while work productivity of employees of production at PT. Tirta Mumbul Jaya Abadi is in very high category with a score of 2,368. From the analysis results it is known that the work discipline has a significant effect on work productivity shown from the value of $t_{\text {test }}>t_{\text {table }}(4.756>$ $2.021)$ or $p$-value $<\alpha(0.000<0.05)$.
\end{abstract}

Keywords : work discipline, work productivity

\section{PENDAHULUAN}

Persaingan dalam dunia bisnis saat ini terjadi dengan begitu cepat dan sangat ketat, hal ini mengakibatkan setiap perusahaan berusaha untuk dapat bertahan 
dalam situasi yang sulit. Iklim bisnis Indonesia tidak terlepas dari adanya isu-isu global yang diakibatkan oleh perubahan struktur pasar Indonesia dalam perdagangan bebas. Solusi yang dapat dilakukan untuk menghadapi persaingan tersebut adalah dengan cara meningkatkan daya saing, baik dalam segi produk maupun kualitas produksi suatu perusahaan. Perusahaan tidak cukup hanya dengan mempunyai modal besar untuk mencapai tujuannya tetapi perusahaan juga harus memperhatikan faktor produksi yang lainnya yaitu alam, tenaga kerja dan keahlian. Dimana keempat faktor tersebut tidak dapat berdiri sendiri, melainkan harus saling mendukung untuk mencapai tujuan secara efektif dan efisien. Dari keempat faktor tersebut faktor tenaga kerja atau manusia dalam hal ini adalah karyawan, merupakan hal yang terpenting karena manusia merupakan pemakai dan penggerak serta penentu segala aktivitas yang ada di perusahaan. Oleh karena itu, antara perusahaan dengan karyawan harus mempunyai kerja sama untuk mencapai tujuan yang diinginkan yang terwujud dalam produktivitas kerja Produktivitas kerja karyawan merupakan faktor yang sangat penting dalam menunjang keberhasilan usaha. Secara filosofi, produktivitas merupakan sikap mental yang selalu berusaha dan mempunyai pandangan bahwa suatu kehidupan hari ini lebih baik dari hari kemarin dan hari esok lebih baik dari hari ini. Secara teknis produktivitas merupakan perbandingan antara hasil yang dicapai dan keseluruhan sumber daya yang dipergunakan. Menurut Wibowo (2012:109) secara konseptual, "produktivitas adalah hubungan antara keluaran atau hasil organisasi dengan masukan yang diperlukan". Kemudian menurut Sunyoto (2012) Produktivitas kerja karyawan adalah perbandingan antara hasil yang dicapai dengan pasar tenaga kerja per satuan waktu dan sebagai tolok ukur jika ekspansi dan aktivitas dari sikap sumber yang digunakan selama produktivitas berlangsung dengan membandingkan jumlah yang dihasilkan dengan setiap sumber yang digunakan. Sedangkan menurut Hasibuan (2007: 94) "produktivitas kerja adalah perbandingan antara output dengan input dimana output harus mempunyai nilai tambah dan teknik pengerjaanya yang lebih baik". Jadi dapat disimpulkan bahwa produktivitas kerja adalah ukuran yang menunjukkan pertimbangan antara input dan output yang dikeluarkan perusahaan serta peran tenaga kerja yang dimiliki persatuan waktu.

Produktivitas tenaga kerja dipengaruhi oleh banyak faktor, menurut Sedarmayanti (2009) faktor yang mempengaruhi produktivitas kerja yaitu sikap mental (motivasi kerja, disiplin kerja, etika kerja), pendidikan, keterampilan, manajemen, hubungan industrial pancasila, tingkat penghasilan, gizi dan kesehatan, jaminan sosial, lingkungan dan iklim kerja, sarana produksi, teknologi, kesempatan berprestasi. Untuk mengukur produktivitas kerja karyawan indikator yang digunakan yaitu kemampuan, meningkatkan hasil yang dicapai, semangat kerja, pengembangan diri, mutu, efisiensi.

Dalam upaya meningkatkan produktivitas kerja karyawan, setiap perusahaan harus memperhatikan faktorfaktor yang mempengaruhi produktivitas kerja. Salah satu faktor yang sangat penting adalah disiplin kerja. Menurut Handoko (2001) disiplin adalah kegiatan manajemen untuk menjalankan standar-standar organisasional. Kemudian menurut Rivai (2010) disiplin kerja adalah suatu alat yang digunakan para manajer untuk berkomunikasi dengan karyawan agar mereka bersedia untuk mengubah suatu perilaku serta sebagai suatu upaya untuk meningkatkan kesadaran dan kesediaan seseorang mentaati semua peraturan perusahaan dan norma-norma sosial yang berlaku. Jadi dapat disimpulkan bahwa disiplin kerja adalah sikap yang tercermin dari perbuatan atau tingkah laku karyawan, berupa kepatuhan atau ketaatan terhadap peraturan dan ketentuan yang ditetapkan oleh perusahaan.

Menurut Mangkunegara (2013) terdapat dua bentuk disiplin kerja yaitu disiplin preventif dan disiplin korektif. Disiplin preventif adalah suatu upaya untuk menggerakkan pegawai mengikuti dan mematuhi pedoman kerja, aturan-aturan yang telah digariskan perusahaan. Tujuan 
dasarnya adalah untuk menggerakkan pegawai berdisiplin diri. Dengan cara preventif, pegawai dapat memelihara dirinya terhadap peraturan-peraturan perusahaan. Pemimpin perusahaan mempunyai tanggung jawab dalam membangun iklim organisasi dengan disiplin korektif. Begitu pula pegawai harus dan wajib mengetahui, memahami semua pedoman kerja serta peraturan-peraturan yang ada dalam organisasi. Disiplin preventif merupakan suatu sistem yang berhubungan dengan kebutuhan kerja semua bagian sistem yang ada dalam organisasi. Jika sistem organisasi baik, maka diharapkan akan lebih mudah menegakkan disiplin kerja. Sedangkan disiplin korektif adalah suatu upaya menggerakkan pegawai dalam menyatukan suatu peraturan dan mengarahkan untuk tetap mematuhi peraturan sesuai dengan pedoman yang berlaku pada perusahaan. Pada disiplin korektif, pegawai yang melanggar disiplin perlu diberikan sanksi sesuai dengan peraturan yang berlaku. Tujuan pemberian sanksi adalah untuk memperbaiki pegawai pelanggar, memelihara peraturan yang berlaku, dan memberikan pelajaran kepada pelanggar.

Menurut Sastrohadiwiryo (2003) tujuan pembinaan disiplin kerja karyawan ada lima yaitu pertama agar karyawan menaati segala peraturan dan kebijakan ketenagakerjaan baik secara tertulis maupun tidak tertulis, serta melaksanakan perintah manajemen. Kedua agar karyawan mampu melaksanakan dengan sebaikbaiknya serta mampu memberikan pelayanan maksimum kepada pihak tertentu yang berkepentingan dengan perusahaan sesuai dengan bidang pekerjaan yang diberikan kepadanya. Ketiga agar karyawan mampu menggunakan dan memelihara sarana dan prasarana barang dan jasa perusahaan dengan sebaik-baiknya. Keempat agar karyawan mampu bertindak dan berperilaku sesuai dengan norma-norma yang berlaku pada perusahaan. Kelima agar karyawan mampu menghasilkan produktivitas yang tinggi sesuai dengan harapan perusahaan, baik dalam jangka pendek maupun dalam jangka panjang.
Terdapatnya disiplin kerja dalam perusahaan akan membuat karyawan dapat menjalankan tugas-tugas yang dibebankan kepadanya dengan baik. Karyawan yang disiplin dan patuh terhadap norma-norma yang berlaku dalam perusahaan dapat meningkatkan produktivitas dan prestasi kerja karyawan yang bersangkutan. Indikator tingkat kedisiplinan karyawan suatu perusahaan menurut Hasibuan (2007) yaitu tujuan dan kemampuan, teladan pemimpin, balas jasa, keadilan, pengawasan melekat (waskat) sanksi/hukuman, ketegasan, hubungan kemanusiaan. Hilangnya disiplin kerja akan berpengaruh terhadap efisiensi dan efektivitas pekerjaan yang berpengaruh keseluruhan terhadap produktivitas karyawan. Dengan adanya kedisiplinan maka diharapkan pekerjaan akan semakin efektif. Tingginya tingkat kedisiplinan maka akan menimbulkan gairah kerja dan semangat kerja yang tinggi. Kualitas dan kuantitas pekerjaan akan semakin baik dan dapat menyelesaikan pekerjaan tepat pada waktunya. Hal ini akan berdampak pada terwujudnya tujuan perusahaan yang hendak dicapai. Menurut Sinungan (2003) disiplin mendorong produktivitas atau disiplin merupakan sarana penting untuk mencapai produktivitas. Anoraga (2004) juga mengatakan bahwa produktivitas kerja pegawai dapat terlaksana sesuai dengan harapan organisasi, maka tiada lain kuncinya adalah disiplin. Sehingga dari pendapat di atas dapat dikatakan ketika karyawan memiliki disiplin yang baik maka produktivitas kerjanya juga akan baik.

Salah satu perusahaan yang memperhatikan produktivitas kerja karyawan adalah PT. Tirta Mumbul Jaya Abadi yang beralamat di Jalan Melati No.9 Singaraja, Bali. PT. Tirta Mumbul Jaya Abadi dengan Merk dagang "Yeh Buleleng" merupakan satu - satunya badan usaha milik Pemerintah Kabupaten Buleleng yang bergerak dalam bidang usaha air minum dalam kemasan atau dengan istilah AMDK (Air Minum Dalam Kemasan) yaitu air minum yang siap di konsumsi secara langsung tanpa harus melalui proses pemanasan terlebih dahulu karena sudah melalui beberapa tahapan proses filterisasi dan sterilisasi yang diyakini aman dan 
dapat dipertanggungjawabkan dari sisi mutu dan kualitasnya. Air minum dalam kemasan merupakan air yang dikemas dalam berbagai bentuk wadah/kemasan 19 Liter (gallon), $1500 \mathrm{ml}, 600 \mathrm{ml}, 330 \mathrm{ml}$ (botol), dan $250 \mathrm{ml}$ (cup). PT. Tirta Mumbul Jaya Abadi tetap berusaha meningkatkan kinerja pegawainya, seiring dengan misi PT. Tirta Mumbul Jaya Abadi untuk menjadikan "Yeh Buleleng" air minumnya masyarakat Bali melalui peningkatan produktivitas kerja secara optimal atas pangsa pasar, nilai tambah dan pertumbuhan usaha.

Berdasarkan observasi yang dilakukan diperoleh informasi-informasi mengenai disiplin kerja dan hasil produksi PT. Tirta Mumbul Jaya Abadi di tahun 2016. Dari data yang diperoleh dapat diketahui bahwa produktivitas kerja karyawan masih rendah yaitu dapat dilihat dari belum tercapainya target produksi perusahaan pada tiap bulannya. Pada bulan Januari target produksi yang direncakan yaitu sebesar 119.000 unit dan hasil produksi yang dicapai hanya sebesar 96.070 unit. Selanjutnya pada bulan Pebruari target produksi yang direncanakan sebesar 111.000 unit dan hasil produksi yang dicapai hanya sebesar 71.382 unit. Kemudian pada bulan Maret target produksi yang direncanakan sebesar 124.500 unit dan hasil produksi yang dicapai hanya sebesar 89.648 unit. Pada bulan April target produksi yang direncakan yaitu sebesar 125.600 unit dan hasil produksi yang dicapai hanya sebesar 94.891 unit. Kemudian pada bulan Mei target produksi yang direncakan yaitu sebesar 124.600 unit dan hasil produksi yang dicapai hanya sebesar 90.184 unit. Pada bulan Juni target produksi yang direncakan yaitu sebesar 120.800 unit dan hasil produksi yang dicapai hanya sebesar 82.505 unit. Kemudian pada bulan Juli target produksi yang direncakan yaitu sebesar 120.530 unit dan hasil produksi yang dicapai hanya sebesar 113.376 unit. Pada bulan Agustus target produksi yang direncakan yaitu sebesar 124.900 unit dan hasil produksi yang dicapai hanya sebesar 106.279 unit. Kemudian pada bulan September target produksi yang direncakan yaitu sebesar 117.070 unit dan hasil produksi yang dicapai hanya sebesar 100.264 unit. Pada bulan Oktober target produksi yang direncanakan dapat tercapai yaitu target produksi yang direncanakan sebesar 123.100 unit dan hasil produksinya sebesar 131.172 unit. Kemudian pada bulan November dan Desember kembali target produksi yang direncakan tidak dapat tercapai. Dimana pada bulan November target produksinya sebesar 124.800 unit dan hasil produksi yang tercapai hanya 118.208 unit. Kemudian pada bulan Desember target produksi yang direncanakan sebesar 124.100 unit dan hasil produksi yang dapat dicapai hanya sebesar 112.082 unit. Dari bulan Januari sampai Desember hanya pada bulan Oktober saja target produksi yang telah direncanakan sebelumnya dapat tercapai. Selain hasil produksi, apabila dilihat dari persentase pertumbuhan pada hasil produksi dapat dilihat bahwa persentase pertumbuhannya cenderung berfluktuasi. Persentase pertumbuhan hasil produksi terendah terjadi pada bulan Pebruari sebesar $-25,70 \%$ dan persentase pertumbuhan hasil produksi tertinggi terjadi pada bulan Juli sebesar $37,42 \%$.

Dari observasi yang telah dilakukan hal yang mengakibatkan belum tercapainya target produksi yang telah ditetapkan perusahaan adalah masih rendahnya disiplin kerja karyawan. Rendahnya disiplin kerja karyawan dapat dilihat dari tingkat absensi yang masih cukup tinggi. Ketika karyawan banyak yang absen maka proses produksi akan mengalami kendala, kendala yang terjadi yaitu kekurangan personil dalam menjalankan proses produksi. Ketika perusahaan kekurangan personil dalam proses produksinya secara otomatis target produksi yang telah direncanakan akan sulit untuk tercapai maka pada akhirnya akan berakibat pada rendahnya produktivitas kerja karyawan. Dari hasil observasi awal diperoleh data bahwa persentase tingkat absensi karyawan pada tahun 2016 mengalami fluktuasi. Pada bulan Januari persentase absensi karyawan sebesar $10,92 \%$, kemudian pada bulan Pebruari persentase absensi karyawan turun menjadi $6,07 \%$, lalu pada bulan Maret persentase absensi karyawan naik menjadi $6,32 \%$. Pada bulan April persentase 
absensi karyawan naik menjadi 8,73\%, kemudian pada bulan Mei persentase absensi karyawan turun menjadi 6,95\%. Pada bulan Juni persentase absensi karyawan naik menjadi $9,22 \%$, lalu pada bulan Juli persentase absensi karyawan naik menjadi $9,42 \%$, kemudian pada bulan Agustus persentase absensi karyawan turun menjadi 5,56\%. Pada bulan September persentase absensi karyawan naik menjadi $9,14 \%$, kemudian pada bulan Oktober persentase absensi karyawan turun menjadi 5,48\%, Pada bulan November persentase absensi karyawan naik menjadi $9,88 \%$, dan pada bulan Desember persentase absensi karyawan kembali naik menjadi $10,92 \%$. Dari persentase absensi karyawan tiap bulan dapat diketahui bahwa persentase absensi karyawan tertinggi terjadi pada bulan Januari dan Desember sebesar 10,92\% dan persentase absen karyawan terendah terjadi pada bulan Oktober sebesar 5,48\%. Tingginya tingkat absensi akan mempengaruhi proses produksi pada perusahaan dan akan dapat menyebabkan jadwal produksi tertunda, sehingga hal ini akan membuat target produksi yang telah ditetapkan sebelumnya sulit untuk tercapai. Sedangkan apabila absensi karyawan dapat diperkecil akan membuat proses produksi dan jadwal produksi dapat sesuai dengan harapan perusahaan yang nantinya akan terwujud pada tercapainya target produksi yang telah direncanakan sebelumnya. Keadaan ini dapat dilihat pada bulan Oktober yaitu pada bulan Oktober persentase absensi karyawan terendah yaitu sebesar 5,48\%. Jika dilihat dari rekapitulasi hasil produksi masing-masing bulannya hanya pada bulan Oktober sajalah target produksi yang telah direncanakan sebelumnya dapat tercapai yaitu target produksi sebesar 123.100 unit dan hasil produksi sebesar 131.172 unit. Sehingga dapat dikatakan ada hubungan antara tingkat absensi karyawan dengan hasil produksi perusahaan.

Penelitian ini bertujuan untuk mengetahui disiplin kerja karyawan bagian produksi pada PT. Tirta Mumbul Jaya Abadi tahun 2016, produktivitas kerja karyawan bagian produksi pada PT. Tirta Mumbul Jaya Abadi tahun 2016, dan pengaruh disiplin kerja terhadap produktivitas kerja karyawan bagian produksi pada PT. Tirta Mumbul Jaya Abadi tahun 2016.

\section{METODE PENELITIAN}

Penelitian ini merupakan jenis penelitian kausal. Penelitian dengan menggunakan pendekatan kausal adalah penelitian yang tujuannya untuk mengetahui sejauh mana hubungan sebab akibat antara variabel $\mathrm{X}$ dan variabel $\mathrm{Y}$. Penelitian ini terdiri dari dua variabel yaitu disiplin kerja $(X)$ sebagai variabel bebas dan produktivitas kerja $(Y)$ sebagai variabel terikat.

Populasi dalam penelitian ini adalah karyawan bagian produksi PT. Tirta Mumbul Jaya Abadi yang berjumlah 42 orang. Karena populasi dalam penelitian ini kurang dari 100 maka penelitian ini termasuk penelitian populasi. Arikunto (2006) menyatakan apabila populasi kurang dari 100 , lebih baik diambil semua hingga penelitiannya merupakan penelitian populasi.

Pengumpulan data dilakukan dengan metode kuesioner/angket dan metode dokumentasi. Metode kuesioner digunakan untuk memperoleh data tentang disiplin kerja dan produktivitas kerja karyawan. Sedangkan metode dokumentasi digunakan sebagai teknik pengumpulan data yang tidak langsung ditujukan kepada subjek penelitian, melainkan melalui pengumpulan dokumen-dokumen. Adapun dokumen yang terkait dengan penelitian ini adalah data absensi karyawan, jumlah karyawan, dan hasil produksi pada PT. Tirta Mumbul Jaya Abadi Tahun 2016.

Instrumen penelitian adalah alat yang digunakan peneliti dalam pengumpulan data. Instrumen dalam penelitian ini yaitu menggunakan kuesioner/angket. Kuesioner/angket adalah seperangkat pertanyaan tertulis yang diberikan kepada subjek penelitian untuk dijawab sesuai dengan keadaan subjek yang sebenarnya. Kuesioner/angket yang digunakan dalam penelitian ini adalah jenis angket tertutup. Angket tertutup merupakan angket yang sudah disediakan jawabannya sehingga responden tinggal memilih. Angket tertutup dalam penelitian ini disajikan dalam bentuk skala likert dengan 
lima alternatif jawaban sehingga responden tinggal memberi tanda silang $(x)$ pada jawaban yang tersedia. Alternatif jawaban yang digunakan dalam penelitian ini yaitu sangat setuju (SS) dengan skor 5 , setuju (S) dengan skor 4, kurang setuju (KS) dengan skor 3, tidak setuju (TS) dengan skor 2, dan sangat tidak setuju (STS) dengan skor 1 .

Instrumen penelitian sebelum digunakan maka terlebih dahulu diuji dengan dua teknik pengujian yaitu uji validitas dan uji reliabilitas. Uji validitas adalah suatu ukuran yang menunjukkan tingkat-tingkat kevalidan atau kesahihan suatu instrumen (Arikunto, 2006). Rumus yang digunakan untuk menguji kevalidan suatu instrumen adalah nilai korelasi product moment dan menggunakan bantuan program SPSS 16 for Windows. Valid atau tidaknya suatu butir atau item pertanyaan dapat ditentukan menggunakan kriteria dengan ketentuan pertanyaan dalam angket dikatakan valid apabila $r$ hitung ( $r x y)$ lebih besar dari $r$ tabel $\left(r_{\text {tabel }}\right)$. Dari hasil uji validiitas yang telah dilakukan maka di dapatkan hasil yaitu pada variabel disiplin kerja dengan jumlah pernyataan sebanyak 25 dapat diketahui bahwa sebanyak 4 pernyataan dinyatakan tidak valid dan sisanya 21 pernyataan dinyatakan valid. Kemudian pada variabel produktivitas kerja dengan jumlah pernyataan sebanyak 15 dapat diketahui bahwa sebanyak 2 pernyataan dinyatakan tidak valid dan sisanya 13 pernyataan dinyatakan valid. Sedangkan uji reliabilitas digunakan untuk mengukur tingkat keandalan atau keakuratan suatu instrumen penelitian (Arikunto, 2006). Uji reliabilitas untuk instrumen penelitian ini adalah menggunakan rumus Cronbach's Alpha dan menggunakan bantuan program SPSS 16 for Windows. Dari hasil uji yang dilakukan dengan menggunakan Cronbach's Alpha diperoleh nilai koefisien 0,891 untuk instrumen variabel disiplin kerja dan 0,881 untuk instrumen variabel produktivitas kerja. Nilai dari Cronbach's Alpha variabel disiplin kerja dan produktivitas kerja berada pada interval koefisien $0,80-1,00$ yang artinya instrumen variabel disiplin kerja dan variabel produktivitas kerja berada pada tingkat hubungan yang sangat tinggi sehingga intrumen variabel disiplin kerja dan produktivotas kerja dinyatakan reliabel.

Jenis data yang digunakan dalam penelitian ini adalah data kuantitatif yaitu data yang berbentuk angka atau bilangan. Dalam penelitian ini yang termasuk dalam data kuantitatif adalah data hasil produksi, data absensi karyawan, dan data hasil jawaban kuesioner mengenai disiplin kerja dan produktivitas kerja. Sumber data yang digunakan dalam penelitian ini adalah sumber data primer dan sumber data sekunder. Sumber data primer dalam penelitian ini berupa tanggapan karyawan mengenai disiplin kerja dan produktivitas kerja melalui penyebaran angket kepada karyawan bagian produksi pada PT. Tirta Mumbul Jaya Abadi. Sedangkan sumber data sekunder berkenaan dengan dokumen tentang absensi karyawan, jumlah karyawan, dan hasil produksi pada PT. Tirta Mumbul Jaya Abadi tahun 2016.

Analisis yang digunakan dalam penelitian ini adalah analisis deskriptif dan analisis regresi linear sederhana. Analisis deskriptif digunakan untuk menjawab pertanyaan nomor satu dan dua yaitu untuk mengetahui bagaimana disiplin kerja dan bagaimana produktivitas kerja karyawan bagian produksi pada PT. Tirta Mumbul Jaya Abadi, sedangkan untuk menjawab pertanyaan nomor tiga yaitu untuk mengetahui besarnya pengaruh disiplin kerja terhadap produktivitas kerja adalah dengan menggunakan data hasil jawaban kuesioner yang diolah dengan menggunakan program SPSS 16 for windows melalui analisis regresi linear sederhana.

\section{HASIL DAN PEMBAHASAN Hasil}

Berdasarkan data yang diperoleh dari hasil kuesioner, disiplin kerja karyawan bagian produksi pada PT. Tirta Mumbul Jaya Abadi tahun 2016 dapat dilihat pada tabel 1 sebagai berikut. 
Tabel 1. Hasil Kuesioner Disiplin Kerja Karyawan Bagian Produksi pada PT. Tirta Mumbul Jaya Abadi Tahun 2016

\begin{tabular}{lc}
\hline \multicolumn{1}{c}{ Indikator Disiplin Kerja } & \\
\hline Tujuan dan kemampuan & \\
Teladan pemimpin & \\
Balas jasa & 3 \\
Keadilan & 3 \\
Pengawasan melekat (waskat) & 3 \\
Sanksi hukuman & \\
Ketegasan & 5 \\
Hubungan kemanusiaan & \\
\hline \multicolumn{1}{c}{ Total } & 3.7 \\
\hline
\end{tabular}

\begin{tabular}{lc} 
Skor & Kategori \\
\cline { 2 - 2 } 728 & Sangat baik \\
541 & Sangat baik \\
318 & Baik \\
335 & Baik
\end{tabular}

$355 \quad$ Sangat baik

$366 \quad$ Sangat baik

$536 \quad$ Sangat baik

$548 \quad$ Sangat baik

3.727 Sangat baik

Berdasarkan tabel 1 di atas, maka dapat dijelaskan bahwa secara keseluruhan total disiplin kerja karyawan bagian produksi pada PT. Tirta Mumbul Jaya Abadi tahun 2016 berada pada kategori sangat baik, dengan skor disiplin kerja sebesar 3.727. Skor disiplin kerja tersebut berada pada rentang kriteria klasifikasi antara $3.705,4-4.410$

Produktivitas kerja karyawan karyawan bagian produksi pada PT. Tirta Mumbul Jaya Abadi tahun 2016 dapat dilihat pada tabel 2 sebagai berikut

Tabel 2. Hasil Kuesioner Produktivitas Kerja Karyawan Bagian Produksi pada PT. Tirta Mumbul Jaya Abadi Tahun 2016

\begin{tabular}{lcc}
\hline \multicolumn{1}{c}{ Indikator Disiplin Kerja } & Skor & Kategori \\
\hline Kemampuan & 357 & Sangat tinggi \\
Meningkatkan hasil yang dicapai & 363 & Sangat tinggi \\
Semangat kerja & 364 & Sangat tinggi \\
Pengembangan diri & 546 & Sangat tinggi \\
Mutu & 367 & Sangat tinggi \\
Efisiensi & 371 & Sangat tinggi \\
\hline \multicolumn{1}{c}{ Total } & 2.368 & Sangat tinggi \\
\hline
\end{tabular}

Berdasarkan tabel 2 di atas, maka dapat dijelaskan bahwa secara keseluruhan total produktivitas kerja karyawan bagian produksi pada PT. Tirta Mumbul Jaya Abadi tahun 2016 berada pada kategori sangat tinggi, dengan skor produktivitas kerja sebesar 2.368. Skor disiplin kerja tersebut

Tabel 3. Hasil Uji t untuk Variabel Disiplin Kerja Terhadap Produktivitas Kerja

\begin{tabular}{|c|c|c|c|c|c|c|}
\hline \multicolumn{7}{|c|}{ Coefficients $^{2}$} \\
\hline & & Unstandardize & Coefficients & $\begin{array}{l}\text { Standardized } \\
\text { Coefficients }\end{array}$ & & \\
\hline \multicolumn{2}{|l|}{ Model } & B & Std. Error & Beta & $\mathrm{t}$ & Sig. \\
\hline \multirow[t]{2}{*}{1} & (Constant) & 11.407 & 4.353 & & 2.621 & .012 \\
\hline & Disiplin Kerja & .465 & .098 & .601 & 4.756 & .000 \\
\hline
\end{tabular}


Dari hasil perhitungan di atas, pengujian hipotesis dilakukan dengan jumlah populasi sebanyak 42 orang, sehingga diperoleh $\mathrm{df}=\mathrm{n}-\mathrm{k}=42-2=40$, sehingga $t_{\text {tabel }}$ dengan $d f=40$ adalah sebesar 2,021. Berdasarkan hasil analisis data yang dapat dilihat pada tabel 3 menunjukkan bahwa variabel disiplin kerja berpengaruh secara signifikan terhadap produktivitas kerja karena hasil analisis menunjukkan bahwa nilai $t_{\text {hitung }}=4,756$ ? $t_{\text {tabel }}=2,021$ dan nilai $p$-value sebesar $0,000<\alpha=0,05$ maka $\mathrm{H}_{0}$ ditolak dan $\mathrm{H}_{\mathrm{a}}$ diterima. Jadi dapat disimpulkan bahwa variabel disiplin kerja memiliki pengaruh yang signifikan terhadap produktivitas kerja karyawan bagian produksi pada PT. Tirta Mumbul Jaya Abadi tahun 2016.

Untuk menggambarkan besarnya pengaruh disiplin kerja terhadap produktivitas kerja, maka dapat diketahui dari hasil analisis koefisien determinasi, yang ditunjukkan dengan nilai $\mathrm{R}$ Square. Hasil analisis koefisien determinasi dapat dilihat pada tabel 4 sebagai berikut.

Tabel 4. Hasil Perhitungan Koefisien Determinasi

\begin{tabular}{|c|c|c|c|c|}
\hline \multicolumn{5}{|c|}{ Model Summary } \\
\hline Model & $\mathrm{R}$ & R Square & $\begin{array}{l}\text { Adjusted R } \\
\text { Square }\end{array}$ & $\begin{array}{l}\text { Std. Error of the } \\
\text { Estimate }\end{array}$ \\
\hline 1 & $.601^{a}$ & .361 & .345 & 6.09708 \\
\hline
\end{tabular}

Berdasarkan hasil analisis data dengan menggunakan program SPSS 16.0 for windows yang dapat dilihat pada tabel 4 menunjukkan bahwa besarnya pengaruh variabel disiplin kerja terhadap variabel produktivitas kerja sebesar 0,361 sehingga besarnya sumbangan pengaruh variabel disiplin kerja terhadap produktivitas kerja adalah sebesar $36,1 \%$. Hal ini berarti produktivitas kerja karyawan bagian produksi pada PT. Tirta Mumbul Jaya
Abadi sebesar 36,1 \% dipengaruhi oleh variabel disiplin kerja sedangkan sisanya $63,9 \%$ dipengaruhi oleh faktor lain yang tidak termasuk dalam penelitian ini.

Berdasarkan hasil analisis data, untuk mengetahui persamaan regresi pengaruh disiplin kerja terhadap produktivitas kerja karyawan bagian produksi pada PT. Tirta Mumbul Jaya Abadi digunakan nilai Unstandardized Coefficients yang dapat dilihat pada tabel 5

Tabel 5. Hasil Perhitungan Koefisien Beta

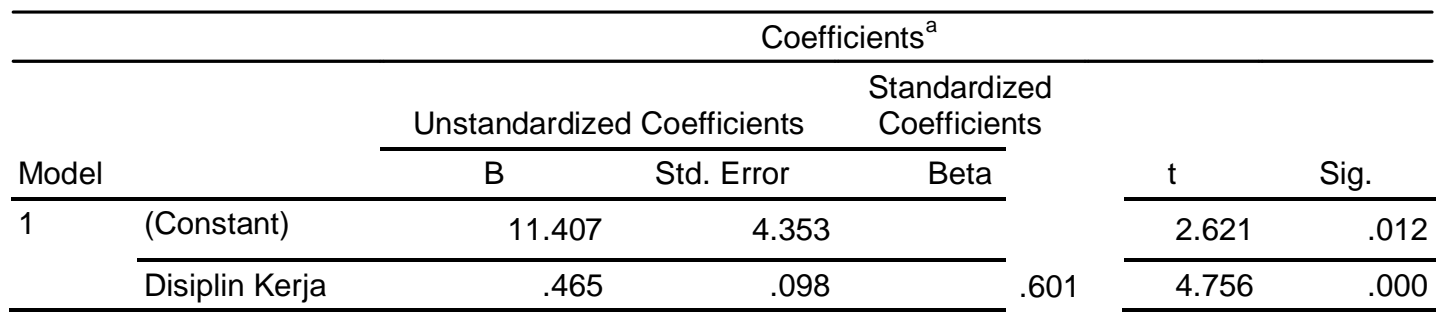

Berdasarkan hasil analisis data yang dapat dilihat pada tabel 5 maka dapat dibuat persamaan regresi untuk menggambarkan pengaruh disiplin kerja terhadap produktivitas kerja yaitu sebagai berikut.

$\hat{Y}=11,407+0,465 X$

Keterangan :

$\hat{\mathrm{Y}} \quad=$ Produktivitas kerja

$\mathrm{bX}=$ Disiplin kerja
Berdasarkan model persamaan regresi yang terbentuk, dapat diinterpretasikan bahwa nilai konstanta sebesar 11,407 menunjukkan jika variabel disiplin kerja $(X)$ bernilai konstan atau nol, maka variabel produktivitas kerja (Y) memiliki nilai positif sebesar 11,407. Variabel disiplin kerja (X) memiliki koefisien positif sebesar 0,465. Nilai koefisien regresi yang positif menunjukkan bahwa disiplin 
kerja $(X)$ berpengaruh positif terhadap produktivitas kerja (Y). Hal ini menggambarkan bahwa peningkatan disiplin kerja $(X)$ sebesar satu satuan akan dapat meningkatkan produktivitas kerja $(\mathrm{Y})$ sebesar nilai koefisien beta variabel bebas dikalikan dengan besar kenaikan yang terjadi.

\section{Pembahasan}

Berdasarkan hasil analisis data yang telah dilakukan maka dapat diketahui bahwa disiplin kerja berpengaruh terhadap produktivitas kerja karyawan bagian produksi pada PT. Tirta Mumbul Jaya Abadi. Hasil ini menunjukkan bahwa apabila karyawan PT. Tirta Mumbul Jaya Abadi memiliki disiplin kerja yang baik maka akan membantu peningkatan produktivitas kerja karyawan. Sebaliknya apabila karyawan PT. Tirta Mumbul Jaya Abadi memiliki disiplin kerja yang tidak baik maka akan dapat menurunkan produktivitas kerja karyawan. Sehingga dalam upaya meningkatkan produktivitas kerja karyawan salah satu cara yang dapat dilakukan yaitu dengan memperhatikan disiplin kerja karyawan. Seseorang akan melaksanakan tugasnya dengan baik dan penuh rasa tanggung jawab bila karyawan tersebut memiliki disiplin kerja yang tinggi. Untuk mengusahakan selalu terbinanya sikap disiplin kerja yang tinggi, maka diperlukan peraturan dan hukuman dalam perusahaan tersebut. Sehingga dapat dikatakan disiplin kerja adalah salah satu syarat untuk dapat membantu karyawan bekerja secara produktif yang nantinya akan membantu peningkatan produktivitas kerja karyawan. Hasil penelitian ini sejalan dengan pendapat yang dikemukakan oleh Sedarmayanti (2009) yang menjelaskan bahwa salah satu faktor yang mempengaruhi produktivitas kerja adalah disiplin kerja. Senada dengan itu, Yulk (dalam Siagian, 2002) menyatakan bahwa disiplin merupakan faktor utama yang mempengaruhi produktivitasnya. Kemudian penelitian ini juga sejalan dengan dengan pendapat yang dikemukakan oleh Sutrisno (2009) yang menyatakan bahwa produktivitas kerja pegawai dalam suatu organisasi sangat dipengaruhi oleh disiplin pegawai. Apabila di antara pegawai sudah tidak menghiraukan kedisiplinan kerja, maka dapat dipastikan produktivitas kerja akan menurun. Padahal untuk mendapatkan produktivitas kerja sangat diperlukan kedisiplinan dari para pegawai.

Hasil penelitian ini juga didukung oleh hasil penelitian terdahulu yang dilakukan oleh Kusumawarni (2007) yang menunjukkan bahwa terdapat pengaruh yang signifikan antara disiplin kerja terhadap produktivitas kerja. Penelitian lain yang mendukung hasil peneltian ini yaitu penelitian yang dilakukan oleh Ismanto (2005), hasil penelitian Nano Iswanto menunjukkan bahwa variabel disiplin kerja berpengaruh signifikan terhadap produktivitas kerja. Penelitian selanjutnya yang mendukung hasil penelitian ini adalah penelitian yang dilakukan oleh Usman (2016), berdasarkan hasil penelitian Ismail Usman disiplin kerja berpengaruh signifikan terhadap produktivitas kerja.

\section{SIMPULAN DAN SARAN}

Berdasarkan hasil penelitian dan pembahasan, maka dapat disimpulkan yaitu disiplin kerja karyawan bagian produksi pada PT. Tirta Mumbul Jaya Abadi secara total berada pada kategori sangat baik, hal ini dibuktikan dari hasil jawaban kuesioner dengan skor disiplin kerja sebesar 3.727 berada pada kategori sangat baik yaitu pada rentang kriteria klasifikasi antara 3.705,4 - 4.410. Sedangkan produktivitas kerja karyawan bagian produksi pada PT. Tirta Mumbul Jaya Abadi secara total berada pada kategori sangat tinggi, hal ini dibuktikan dari hasil jawaban kuesioner dengan skor produktivitas kerja sebesar 2.368 berada pada kategori sangat tinggi yaitu pada rentang kriteria klasifikasi antara 2.294,2 2.730. Disiplin kerja berpengaruh secara signifikan terhadap produktivitas kerja karyawan bagian produksi pada PT. Tirta Mumbul Jaya Abadi. Hal ini dapat ditunjukkan dari hasil analisis regresi linear sederhana yang menunjukkan bahwa nilai $t_{\text {hitung }}=4,756>t_{\text {tabel }}=2,021$ dan nilai $p$ value sebesar $0,000<\alpha=0,05$. Besarnya pengaruh disiplin kerja terhadap produktivitas kerja karyawan bagian produksi pada PT. Tirta Mumbul Jaya Abadi ditunjukkan dari hasil koefisien 
determinasi pada bagian $R$ Square sebesar 0,361. Hal ini menunjukkan bahwa produktivitas kerja karyawan bagian produksi pada PT. Tirta Mumbul Jaya Abadi sebesar 36,1 \% dipengaruhi oleh variabel disiplin kerja sedangkan sisanya $63,9 \%$ dipengaruhi oleh faktor lain yang tidak termasuk dalam penelitian ini.

Berdasarkan simpulan di atas, maka dapat dikemukakan beberapa saran. Bagi perusahaan yaitu PT. Tirta Mumbul Jaya Abadi, agar tetap memperhatikan disiplin kerja dan produktivitas kerja karyawan karena dalam penelitian ini membuktikan bahwa disiplin kerja berpengaruh terhadap produktivitas kerja, sehingga perusahaan hendaknya dapat mempertahankan dan meningkatkan disiplin kerja sehingga pada akhirnya akan dapat meningkatkan produktivitas kerja karyawan. Dari hasil yang diperoleh total skor variabel disiplin kerja berada pada kategori sangat baik, namun pada indikator balas jasa dan keadilan masih belum mencapai kategori sangat baik. Hal ini perlu diperhatikan lagi oleh perusahaan, perusahaan sebaiknya bisa memberikan balas jasa yang lebih baik lagi pada karyawan misalnya memberikan penghargaan (reward) berupa bonus pada karyawan yang memiliki tingkat disiplin kerja yang baik dan juga pada karyawan yang memiliki prestasi kerja yang baik. Kemudian dari indikator keadilan perusahaan sebaiknya selalu memperhatikan dan menjaga keadilan di dalam memperlakukan setiap karyawan dan menjaga keadilan dalam pemberian tugas kepada setiap karyawan. Hal ini karena ketika karyawan sudah merasa diperlakukan dengan adil maka secara otomatis karyawan akan bekerja dengan baik sehingga pada akhirnya disiplin kerja karyawan juga akan baik. Sedangkan skor variabel produktivitas kerja berada pada kategori sangat tinggi dan tiap indikator pada variabel produktivitas kerja sudah berada pada kategori sangat tinggi, walaupun disiplin kerja dan produktivitas kerja sudah sangat baik perusahaan haruslah bisa mempertahankan dan meningkatkan disiplin kerja dan produktivitas kerja karyawan. Ketika perusahaan sudah dapat mempertahankan dan meningkatkan disiplin kerja karyawan maka diharapkan target produksi dapat tercapai sehingga secara otomatis akan meningkatkan produktivitas kerja karyawan. Kemudian bagi peneliti selanjutnya yang tertarik untuk mengkaji aspek yang serupa mengenai pengaruh disiplin kerja terhadap produktivitas kerja diharapkan dapat mengembangkan penelitian ini lebih lanjut dan dapat menambah variabel lain yang diduga dapat mempengaruhi produktivitas kerja seperti motivasi kerja, lingkungan dan iklim kerja, pendidikan dan variabel lainnya.

\section{DAFTAR PUSTAKA}

Anoraga, P. 2004. Manajemen Bisnis. Jakarta: Rineka Cipta

Arikunto, S. 2006. Prosedur Penelitian: Suatu Pendekatan PrakteK. Jakarta: PT Rineka Cipta

Handoko, H. 2001. Manajemen Personalia dan Sumber Daya Manusia. Jakarta: BPFE

Hasibuan, M.S.P. 2007. Manajemen Sumber Daya Manusia. Edisi Revisi. Jakarta: Bumi Aksara

Ismanto, N. 2005. "Pengaruh Pengalaman Kerja dan Disiplin Kerja terhadap Produktivitas Kerja Karyawan Perusahaan Speaker Aktif Arofah Elektronik di Desa Gribig Kecamatan Gebog Kabupaten Kudus". Skripsi. Tersedia pada (http://lib.unnes.ac.id/322/). Jurusan Ekonomi. Fakultas IImu Sosial, Universitas Negeri Semarang

Kusumawarni, D. $2007 . \quad$ "Pengaruh
Semangat dan Disiplin Kerja
Terhadap Produktivitas Karyawan
Pada Perusahaan Daerah Air
Minum (PDAM) Kabupaten Kudus".
Skripsi. $\quad$ Tersedia $\quad$ pada
(http://lib.unnes.ac.id/982/1.hasprevi
ewThumbnailVersion/2625.pdf).
Jurusan Manajemen Ekonomi.
Fakultas Ekonomi, Universitas
Negeri Semarang


Mangkunegara, A.P. 2013. Manajemen Sumber Daya Manusia Perusahaan. Bandung: PT. Remaja Rosdakarya

Rivai, V. 2010. Manajemen Sumber Daya Manusia Untuk Perusahaan. Jakarta: Raja Grafindo Persada

Sastrohadiwiryo, S. 2003. Manajemen Tenaga Kerja Indonesia Pendekatan Administratif dan Operasional. Jakarta: Bumi Aksara

Sedarmayanti. 2009. Sumber Daya Manusia dan Produktivitas Kerja. Bandung: Mandar Maju

Siagian, S.P. 2002. Kiat Meningkatkan produktivitas Kerja. Jakarta: Rineka Cipta

Sinungan, M. 2003. Manajemen Sumber Daya Manusia. Jakarta: Bumi Aksara

Sunyoto, D. 2012. Teori, Kuesioner, dan Analisis Data Sumber Daya Manusia (Praktik Penelitian). Jakarta: PT. Buku Seru

Sutrisno, E. 2009. Manajemen Sumber Daya Manusia. Jakarta: Kencana

Usman, I. 2016. "Pengaruh Disiplin Kerja terhadap Produktivitas Kerja Karyawan PT. Allo Jaya di Bontang". Skripsi. Tersedia pada (http://ejournal.adbisnis.fisipunmul.ac.id/site/?p=1417). Jurusan Program S1 IImu Administrasi Bisnis. Fakultas IImu Sosial dan IImu Politik, Universitas Mulawarman

Wibowo. 2012. Manajemen Kinerja. Cetakan keenam. Jakarta: Grafindo Persada 